\title{
探索中国铁路配餐的创新空间及潜在商业价值一通过与日本 「駅弁」的对比研究
}

\author{
王盛东 王铭钰 李欣燕 曾宇豪 毛一强 \\ 西南交通大学 \\ DOI:10.32629/ej.v3i3.450
}

\begin{abstract}
[摘要] 随着 “一带一路” 的建设,高铁已成为中国的一张新名片, 但2017年全国人民代表大会上中铁副 总工、中国工程院院士王梦恕说到: “40元的高铁盒饭丢高铁的人”, 更深层次反映出的是中国高铁管 理模式的不足以及美食创新的缺失。虽然目前我国高铁配餐在质量上飞速发展, 但还有一定优化空间。 世界高铁看中国, 中国高铁看西南交大。作为中国轨道交通第一高校, 西南交通大学始终致力于中国高铁 研发与建设中。结合我校特色与自身专业背景, 我们与已成为日本名片之一的駅弁(车站便当)对比, 探索 我国铁路配餐的创新空间和潜在商业价值。
\end{abstract}

[关键词] 中国与日本; 铁路配餐; 创新空间; 商业价值; 精准扶贫

\section{1 中国铁路餐饮现状}

配餐价格。我国铁路配餐价位在 15 -65元不等, 但考虑到性价比, 大多数乘 客还是会自带零食或者方便食品。

食材地域性。一些铁路局会推出本 地菜式, 但从整体来看这些地域美食数 量不多, 且很多订餐属于连锁快餐的外 延, 缺乏中国特色、地域特色。

经营模式。随着我国网络购物和外 卖配送的发展, 乘客已可通过线上APP、 微信小程序等购买车站附近商家的外 卖。某些线路可扫描座位上二维码, 自助 购买餐食和当地特产。这一点极具中国 特色并且十分便利。但是购买的范围仅 限车站附近的少数商家, 选择空间小, 且 价格及配送费高昂。

综上, 我国铁路配餐的定位仅为“乘

企业承担过重的税负, 不利于其发展; 三 简政放权, 精简行政审批程序, 提高办事 效率, 加快工商登记注册制度的改革, 优 化程序, 使非公有制企业能够更加快捷 的注册公司。

\section{3 结语}

非公有制经济虽然在现实中存在很 多困难, 但是每一个新生事物的发展与
客旅途中的便利食品”, 性价比低, 经营 模式单一, 售卖范围狭窄, 产业链没有延 展, 商业价值较低。因此旅客们多选择自 带食品, 真正选择购买铁路配餐的旅客 少之又少。

\section{2 我国与日本相比的优势与} 不足

駅弁性价比优, 品类丰富。駅弁价格 在 $430-3500$ 日元不等, 大多集中在 430 - 1600 日元 (28-104人民币) 之间, 根据 国家物价水平看, 不仅荤素搭配, 摆盘精 美, 性价比也很高。品类繁多, 有详细记 载的就多达2275种, 几乎每一个地区的 每一个车站都至少有一个属于自己品类 的车站便当, 多的如横滨站甚至多达 70 余种。

駅弁文化创新性强。駅弁根据食材、

成熟都是需要成长的, 我国无论是在法 律制度还是政策方面都给与了非公有制 经济以支持, 但是要使非公有制发展的 更好, 需要做的还有很多。

\section{[参考文献]}

[1]杨林瑞,尹良培.中小企业融 资问题的法律研究 [J]. 中国法 学,2003(3):119-128.
季节、地区或年代改变内容及包装, 如春 季的樱花元素, 秋季的枫叶元素。有的包 装会设计成列车头的形状, 极具创新力。 从北海道到九州岛, 特色便当随沿线地 域变化而变化。北海道有乌贼包饭、螃 蟹便当, 横滨有老滋味烧卖, 神户有牛排 饭等。日本的车站便当不仅是旅途中填 饱肚子的食物, 它被打造成带有纪念意 义的产品, 走出铁路, 成为日本的一种文 化。日本还有将全日本有名的駅弁集中 售卖的 “駅弁大会”。足以见得駅弁已成 为一种社会文化。

在经营管理方面, 与日本不同, 中国 铁路配餐企业的食品经营有自主经营和 合资合作经营两种模式。自主经营模式 便于管理, 能最大限度降低铁路食品安 全风险, 取得食品经营各环节的收益, 有

[2] 常继营.新常态下中小企业融资途 径探析[J].财会通讯,2018(11):20-22.

[3]岳文海.中国新型城镇化发展研 究 [D].武汉大学,2013.

[4]靳贞来. 城乡居民收入差距变动 及其影响因素的实证研究 [D]. 南京农业 大学,2006. 
利于打造铁路餐饮品牌, 实现收益最大 化。合资合作经营投资少, 经营风险低, 但对食品经营过程及环节控制力有限, 食品安全风险大, 不利于打造品牌和效 益最大化。现阶段铁路尚未形成统一的 供餐平台, 配餐基地建设和经营开发由 各铁路局自己决定。这种分散式的食品 经营模式, 造成铁路快餐食品在定位、品 类和价位等方面不统一, 即使同一名称 的菜品因出自不同生产企业, 质量、口 味、价格也不相同, 制约了品牌建设的整 体发展。

\section{3 潜在的商业价值与发展建议}

3.1 自主创新品牌营销

打造商业化的铁路餐饮自主创新品 牌, 才能延伸产业链, 进一步取得经济效 益和社会效益, 甚至文化效益。我国人口 多、客流量大、消费需求多元, 要因 “客” 制宜, 铁路餐饮要统筹旅客“吃饱”与“吃 好”的问题。

经营模式创新。通过 “路企合作” 延长铁路配餐商业链, 提高品牌效应。一 是在火车站、地铁站、超市内设立原创
铁路配餐的专柜, 不仅可以方便旅客购 买, 还可以提高铁路餐饮相较于其他方 便食品的竞争力。二是结合线上销售, 拓宽铁路餐饮的销路。把握大众口味趋 势, 实现盈利渠道多元化和铁路配餐普 遍化。

餐品创新。“铁路+美食”, 食材地域 化, 餐品中国化。随着海外游客的增多, 可能会出现外国游客为了体验铁路美食 而选择铁路出行的情况。将铁路配餐向 文化产品转向升级, 使铁路配餐成为地 域特色中的一环。吃地方美食、品中国 味道、用绿色环保、享受身心愉悦、留 下美好中国印象。

\section{2 充分利用国家政策}

中国铁路餐饮的潜在商业价值和创 新可以为我国扶贫攻坚战助力。例如在 无轨火车站中设立铁路配餐的商店, 把 更多具有地域特色的地方美食带入其中, 为铁路餐饮的创新与发展注入活力。不 仅能通过当地取材来降低原料成本, 同 时产品的制作与运输也能够为当地带来 更多的发展机遇, 激发当地经济活力, 助
力精准扶贫。

紧握 “一带一路” 的发展机遇。早 在2013年, 国家主席和总理就提出了建 设 “新丝绸之路经济带” 的战略构想。 近年来高铁外交合作使区域间的商务与 旅游日渐频繁。一带一路高铁线路的陆 续开通，必将有效提升沿线区域餐饮的 蓬勃发展。通过一带一路, 以高铁为承载, 中国也可以将自己的特色美食与文化传 递出去, 同时融合沿线国家的地域特色, 博采众长, 再一次丰富我国铁路配餐。并 通过与沿线各国的交流合作, 吸引外来 投资, 为我国的铁路餐饮业带来更多可 能, 创造经济活力。

\section{[参考文献]}

[1]王东黎, 万军, 孔宪会.铁路餐饮 服务品牌建设与发展 [J]. 铁路节能环保 与安全卫生,2017,7(06):313-315.

[2]程令强。“高铁无轨站”演绎精 准扶贫 [J].新西部,2019,(22):86-87.

[3]王刚,䴙六堂.浅析高速铁路对 “一带一路”沿线区域产业发展的影响 [J]. 产业经济评论,2018,(02):47-53. 